\title{
How Sociology Perspective Influence Law with a Social Contexts? A Book Review “Pokok-Pokok Sosiologi Hukum", Prof Dr Soerjono Soekanto SH MA, Rajawali Pers, 269 Pages, ISBN 979-421-131-1
}

Abraham Abraham

Faculty of Law, Universitas Negeri Semarang, Indonesia

Corresponding author: abraham766hi@students.unnes.ac.id

Abstract: Sociology of law examines why humans obey the law and why it fails to obey the law and the social factors that influence it. as a relatively new branch of sociology, the science of legal sociology was developed to explain the interrelationships of patterns of behavior and law that cannot yet be explained by other branches of social science.

Keywords: Sociology of Law, Book Review, Soerjono Soekanto

How to cite:

Abraham, A. (2021). How Sociology Perspective Influence Law with a Social Contexts? A Book Review "Pokok-Pokok Sosiologi Hukum", Prof Dr Soerjono Soekanto SH MA, Rajawali Pers, 269 Pages, ISBN 979-421-131-1. Indonesian Journal of Advocacy and Legal Services, 3(2), 251-256. https://doi.org/10.15294/ijals.v3i2.34788 


\section{A. Data of Book}

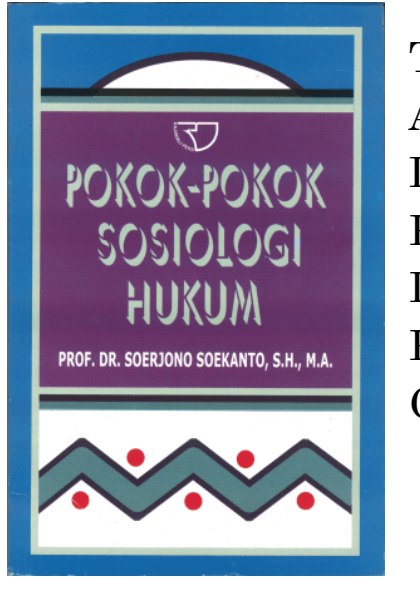

Title

Author(s)

Language

Pages

ISBN

Publisher

City of Publisher : Jakarta

\section{B. Outline in this introductory book:}

1. aspects of the legal field that are important for the development of sociological understanding of social phenomena

2. studies of legal sociology and its problems which will be the foundation for the legal experts and sociologists in understanding the nature and nature of Indonesian law within the framework of Indonesian society

\section{Writer's biography}

Soerjono Soekanto, is Lector of the Head of Sociology and Customary Law at the Faculty of Law, University of Indonesia. Soerjono Soekanto was once the Head of the National Defense Institute Curriculum Section (19651969). He was also the Assistant Dean for Education Administration at the Faculty of social sciences, University of Indonesia (1970-1973), and is now the assistant Dean of Research and Community Service at the Faculty of Law, University of Indonesia (since 1978) concerned, listed as Southeast Asian Specialist at Ohio University and became a Founding Member of the World Association of Lawyers. He holds a Bachelor of Laws degree from the Faculty of the University of Indonesia (1965), a certificate of social sciences research methods from the University of Indonesia (1969), a Master of Arts from the University of California, Betkeley (1970), a Certificate from the Academy of American and International Law, Dallas (19972) and a doctorate in Law from the University of Indonesia (1977). Appointed as a professor of law sociology at the University of Indonesia (1983). 


\section{Review of this book}

Sociology of law is a branch of sociology that studies law in social contexts, about the relationship between society and law, studying analytically and empirically the mutual influence of law with other social phenomena.

\section{Legal Sociology Concepts}

1. Law as social control

Law as a social control (legal certainty) in the sense that the Act carried out is actually carried out by the authorities, law enforcers. The function of the problem of interpretation appears to be prominent, with changes in changes to the factors mentioned above, the law must conduct its business in such a way that conflict conflicts and lameness that may arise do not interfere with public order and productivity.

Social control is an effort to create a balanced condition in society, which aims to create a state of harmony between stability and change in society.

The point is the law as a means of maintaining order and achieving justice. Social control includes all the forces that create and maintain social ties. The law is a means of coercion that protects citizens from actions and threats that endanger themselves and their property.

2. The Law Serves as A Means of Social Engineering

Law can be social engineering: it is a function of law in a conservative sense, this function is needed in every society, including in a society that is undergoing upheaval and development. Includes all the forces that create and maintain social bonds that adhere to the imperative theory of the function of law.

This is intended in order to introduce modern legal institutions to change the minds of the people who so far have not known him, as a consequence of the developing State, which is related to modernization in improving people's lives.

The point is the law as a means of renewal in society. Law can play a role in changing people's thought patterns from traditional thought patterns to rational / modern thought patterns.

3. Legal Authority

Weakening of the legal authority according to O. Notohamidjoyo, among others, because the law does not receive proper support from nonlegal social norms, legal norms are not in accordance with non-legal social 
norms, there is no legal awareness and proper norm awareness, officials' legal officials who are not aware of their obligations to maintain state law, the existence of power and authority, there is a paradigm of reciprocal relations between other social phenomena with the law. In the following sense:

a. The law does not have the proper support from non-legal social norms, the weakening of the value of the system in society in general as a result of modernization

b. Legal norms are not yet not compatible with non-legal social norms, laws that are formed are too progressive so that they are perceived as foreign norms to the people

c. There is no legal awareness and proper norm awareness

d. Legal officials are not aware of their noble obligations to maintain state law, then corrupt, undermine the country's law

e. Central and local governments are trying to dismantle the laws that apply to certain purposes. It can happen that the government, which should support the law as its obligation, has instead betrayed the law

4. A fact that law is only needed for those with low strata while high strata appear to be immune to the law.

Until now, many high-class criminals or so-called White Collar crimes (White Color Crime) who were sentenced very light or even a few were sentenced to be free, because they hold the power and authority that can intervene the law enforcers, this results in those who are stratified high as immune to the law and vice versa the law is only used for those with low strata.

5. Legal Effectiveness and Role of Sanctions

It is a manuscript that contains the socio-legal focus on the role of sanctions in the process of legal effectiveness. Legal effectiveness is a process that aims to make the law effective. The situation can be reviewed on the basis of several benchmarks of effectiveness. According to Suryono the effectiveness of the law includes:

a. The law must be good

- Sociologically (can be accepted by the community)

- Juridically (all written laws governing certain areas of law must be synchronized)

○ philosophically

b. Law enforcers must be good, in the sense that they have carried out their duties and obligations as outlined by applicable law.

c. Facilities available that support the law enforcement process 
d. Community legal awareness

Requirements for community legal awareness:

- Know the law (law awareness)

- Respect for the law (legal attitude)

- Understand its contents (law substance)

- Obedient without being forced (legal behavior)

e. Community legal culture.

There needs to be an implied condition that is Ruth Benedict's view of the existence of a culture of shame, and a culture of guilt when someone violates applicable laws.

\section{Issues of concern in the sociology of law:}

\section{1. community law and social systems}

legal system as part of the social system so that there is no doubt that the law and the social system of society is the study of the sociology of law. only what needs to be investigated is in what circumstances and in how social systems affect the legal system as a sub-system and vice versa

2. law and socio-cultural values

- law as social norms cannot be separated from the values prevailing in society (for example: inheritance law in Tapanuli, a widow is not an heir of her husband, a widow is considered an outsider). this is a reflection of the socio-cultural values of the patrilineal community (draws a line from the father)

- good law is a law that can live in society.

to realize the social values aspired by the community, legal principles are needed as a tool. Most people still live-in rural areas where most Indonesian people feel part of the natural environment and all their behavior need to adjust themselves to the procedures as determined by the natural surroundings. if there is a violation there is a penalty that is to restore the balance of nature (the cosmic mind)

- rules regarding human behavior

it can be seen that from habits passed down through generations from one generation to the next (there are also most who maintain the status quo (status quo: people who don't like change). 
- harmony that still lives in the community also influences the law in order to resolve disputes, the achievement of a compromise (daniel lev: difficult to achieve a certainty of law).

The benefit of sociology of law in real life:

- to provide abilities for understanding law in social contexts

- mastery the conceptions of legal sociology can provide abilities to control the analysis of the effectiveness of law in society both as a means of social control, as a means of changing society and a means to regulate interactions

- provide possibilities and the ability to evaluate the law in society

\section{E. Summary and comments of this book}

So, sociology of law is a sub-discipline of sociology that studies patterns of behavior in society. Sociology of law examines why some people obey the law while others violate the rules? Why do some community groups uphold government regulations, and the others obey customary law? Why do law breakers intentionally break the law? What social conditions allow someone to break the law? How is the law made? For what purpose and who is the law made? And much more that could be the object studies of sociology of law as we know that legal science has an interdisciplinary nature. Where some aspects of law cannot be explained without other scientific disciplines. In other words, sociology comes in order to help the legal work based on the perspective of sociology.

In my opinion, this book is really suitable not only for students but also the lecturers because we can learn about legal on the perspective of sociology and how to overcome the issues in society or how the government make a regulation with discipline of sociology of law

\section{Acknowledgments}

None.

\section{F. Declaration of Conflicting Interests}

The authors states that there is no conflict of interest in the publication of this article.

\section{G. Funding}

None. 